\title{
The natural logarithm transforms the abbreviated injury scale and improves accuracy scoring
}

\author{
Doğal logaritma doğruluk skorlamasını iyileştiren kısaltılmış yaralanma ölçeğini \\ dönüştürmektedir
}

Xu WANG, ${ }^{1}$ Xiaoming GU, ${ }^{2}$ Zhiliang ZHANG, ${ }^{3}$ Fang QIU, ${ }^{1}$ Keming ZHANG ${ }^{1}$

\section{BACKGROUND}

The Injury Severity Score (ISS) and the New Injury Severity Score (NISS) are widely used for anatomic severity assessments, but they do not display a linear relation to mortality. The mortality rates are significantly different between pairs of the Abbreviated Injury Scale (AIS) triplets that generate the same ISS/NISS total.

\section{METHODS}

The Logarithm Injury Severity Score (LISS) is defined as a change in AIS values by raising each AIS severity score (1-6) by taking the natural logarithm to a power of 5.53 multiplied by 1.7987 and then adding the three most severe injuries (i.e. highest AIS), regardless of body region. LISS values were calculated for every patient in three large independent data sets: $3,784,4,436$, and 4,018 patients treated over a six-year period at Class A tertiary comprehensive hospitals in China. The power of LISS to predict morality was then compared with previously calculated NISS values for the same patients in each of the three data sets.

\section{RESULTS}

We found that LISS is more predictive of survival as well (Hangzhou: receiver operating characteristic (ROC): NISS $=0.931$, LISS $=0.949$, p=0.006; Similarly, Zhejiang and Shenyang: ROC NISS vs. LISS, $\mathrm{p}<0.05)$. Moreover, LISS provides a better fit throughout its entire range of predicting (Hosmer-Lemeshow statistic for Hangzhou NISS $=15.76, p=0.027$; LISS $=13.79, p=0.055$; Similarly, for Zhejiang and Shenyang).

\section{CONCLUSION}

LISS should be used as the standard summary measure of human trauma.

Key Words: Prediction of mortality; Abbreviated Injury Scale; Injury Severity Score; New Injury Severity Score; Logarithm Injury Severity Score; LISS.

\section{$\boldsymbol{A M A C}$}

Yaralanma şiddet derecesi skoru (ISS) ve yeni yaralanma şiddet derecesi skoru (NISS) anatomik şiddet derecesinin değerlendirmelerinde yaygın biçimde kullanılmakla birlikte mortaliteyle bir doğrusal ilişki göstermemektedirler. Aynı ISS/NISS toplamını oluşturan kısaltılmış yaralanma ölçeği (AIS) üçlemeleri arasında yapılan ikili karşılaştımalarda ölüm oranları anlamlı derecede farklıdır.

\section{GEREÇ VE YÖNTEM}

Vücudun hangi bölgesinde oluşacaklarına bakılmaksızın en şiddetli üç AIS yaralanmasının doğal logaritmasının üssüne yükseltilen 1.7987 ile 5.53'ün çarpımı yaralanma şiddet derecesi skoru logaritması (LISS) olarak tanımlanmaktadır. Çin'de Hangzhou Üniversitesine bağlı birinci sınıf kapsamlı hastanenin üç kademesinde altı yıllık dönem boyunca tedavi edilen 3.784 hastalık geniş bir veri setinde her hasta için LISS değerleri hesapland1. Her bir veri setinde mortaliteyi öngören LISS'nin istatistiksel gücü aynı hastalar için önceden hesaplanmış NISS değerleriyle karşılaştırıldı.

\section{BULGULAR}

LISS' in sağkalımı daha iyi öngördüğünü saptadık (Hangzhou: Algılayıcı İşletim Eğrisi (ROC): NISS=0,931, LISS $=0,949, p=0,006$ ). Benzer şekilde Zhejiang ve Shenyang: ROC NISS ve LISS, $\mathrm{p}<0.05)$. Ayrica, LISS tüm öngörü erimi boyunca daha iyi bir uyum sağlamaktadır (Hangzhou: Hosmer Lemeshow istatistiği: NISS=15,76, $\mathrm{p}=0,027$; LISS $=13,79, \mathrm{p}=0,055$; benzer şekilde Zhejiang ve Shenyang).

SONUÇ

LISS, insan travmasının standart ölçümü olmalıdır.

Anahtar Sözcükler: Mortalitenin öngörümü; Kısaltılmış Yaralanma Ölçeği; Yaralanma Şiddet Derecesi Skoru; Yeni Yaralanma Şiddet Derecesi Skoru; Yaralanma Şiddet Derecesi Skorunun Logaritmas1; LISS.
Departments of ${ }^{1}$ Emergency, ${ }^{1}$ Orthopedic, Affiliated Hospital of Hangzhou Normal University, Hangzhou; ${ }^{3}$ The College of Life and Environmental Sciences, Hangzhou Normal University, Hangzhou, China.
Hangzhou Normal Üniversitesi Hastanesi,

${ }^{1}$ Acil Kliniği, ${ }^{2}$ Ortopedi Kliniği, Hangzhou; ${ }^{3}$ Hangzhou Normal Üniversitesi Yaşam ve Çevre Bilimleri Fakültesi, Hangzhou, Çin. 
In 1971, the Committee on Automotive Safety published the Abbreviated Injury Scale (AIS) ${ }^{[1]}$ It was revised, expanded and improved repeatedly. The latest was the 2005 edition, update $2008 .{ }^{[2]}$ It is an anatomically based, global severity scoring system that classifies each injury in every body region according to its relative importance on a 6-point ordinal scale from 1 (minor injury) to 6 (currently untreatable). The AIS severity score performs well as a measure of mortality, but that mortality is not the sole determinant of AIS severity. As AIS increased, variability in the survival also increased. ${ }^{[3]}$

Although the AIS provided a rudimentary dictionary of possible injuries, it failed to provide a mechanism to summarize a single patient's multiple injures into a single score. This step was taken by Baker et al. ${ }^{[4]}$ in 1974 with the creation of the Injury Severity Score (ISS). The score is the summation of the squares of the severity digit in the AIS of the most severe injuries, in three of six predefined body regions. An AIS code with a severity of 6 anywhere in the body automatically increases the ISS to 75 .

The ISS has been considered the "gold standard" among anatomic injury severity indicators. It is used to describe trauma populations, to evaluate the quality of trauma care, and to control for case mix in trauma research. ${ }^{[4]}$ The ISS is based on AIS severity values, which are assigned from the patient's hospital files at discharge. The ISS reflects deterioration in patient status after trauma but does not discriminate between deterioration secondary to the natural history of the injury and in-hospital care. Therefore, it may not be a valid instrument for evaluating the quality of trauma care. The ISS has an idiosyncrasy that both impairs its predictive power and complicates its calculation.

Perhaps the most important drawback of the ISS cannot be addressed with statistical techniques: the ISS only considers one injury in each body region. This leads to injuries being overlooked and to less severe injuries occurring in other body regions being included in the calculation over more serious ones in the same body region. A simple modification to the ISS, the New Injury Severity Score (NISS), was designed by Osler et al. ${ }^{[5]}$ in 1997 to counter this problem. The NISS is simply the sum of squares of the three most severe injuries, regardless of body region injured.

Many articles comparing the NISS to the ISS in terms of mortality can be found in the literature. Most of the studies have observed better discrimination and calibration for the NISS, ${ }^{[6-9]}$ and some studies have observed better calibration but equivalent discrimination. ${ }^{[10,11]}$ In addition, a few studies have noted no advantage of the NISS. ${ }^{[12,13]}$

The ISS/NISS have an idiosyncrasy that impairs their predictive power. The International Classification of Disease-Based Severity Score (ICISS) was also discovered to be nonlinear in this group of patients, but was found to be relatively monotonic in terms of its association with mortality. The ICISS has proven to be a better predictor of survival than the ISS, and could be used in place of the ISS/NISS. ${ }^{[14,15]}$ The present findings may help to shed some light on the statistical advantage of the ICISS over the ISS/NSS.

Some studies ${ }^{[16-18]}$ found that the mortality associated with AIS severity combinations that produce identical ISS/NISS is different. ISS/NISS scores with a higher AIS value significantly increased the risk of mortality. they serve to identify specific areas in which the ability to predict survival may be flawed, yet previously not acknowledged. From the above studies, we can guess that higher AIS values contribute more to mortality, and the square of the AIS value cannot be solved according to NISS/ISS scoring rule, which cannot increase the value intervals of AIS.

We therefore tested a simple transformation of the AIS value, a score that we call the natural Logarithm Injury Severity Score (LISS). The LISS is equal to: $\left(\ln \mathrm{A}_{1}\right)^{5.53} \times 1.7987+\left(\ln \mathrm{A}_{2}\right)^{5.53} \times 1.7987+\left(\ln \mathrm{A}_{3}\right)^{5.53} \times$ 1.7987, where "In" indicates natural logarithm. $\mathrm{A}_{1}, \mathrm{~A}_{2}$, and $\mathrm{A}_{3}$ are the three most severe AIS codes, indicating a patient's three most severe injuries, regardless of body region.

This study aimed to investigate whether the LISS statistically outperforms the NISS in predicting inhospital mortality in three populations of 3,784 , 4,436, and 4,018 trauma patients seen in Class A tertiary comprehensive -hospitals: Affiliated Hospital of Hangzhou Normal University, Hangzhou; Zhejiang Provincial People's Hospital, Zhejiang; and Fengtian Hospital Affiliated with Shenyang Medical College, Shenyang, China, respectively, between January 2006 and December 2011. In addition, the study sought to examine whether the mortality associated with AIS severity combinations that produced identical ISSs is different.

\section{MATERIALS AND METHODS}

This retrospective cohort study reviewed data from three hospitals in Hangzhou, Zhejiang, and Shenyang, respectively. The trauma registry contains data for three totals of $10,625,16,486$, and 12,960 patients hospitalized as a result of trauma. The information collected included demographic data, details on the injury, utilization of hospital services, and outcome. Patients with isolated minor or moderate injuries (AIS 1 and 2) to a single body region, deaths on arrival and patients less than 15 years of age were excluded from the study. The study population therefore comprised $3,784,4,436$, and 4,018 patients, respectively. These 
Table 1. Natural logarithm transforms AIS codes

\begin{tabular}{ccccc}
\hline $\begin{array}{c}\text { AIS codes } \\
(\mathrm{A})\end{array}$ & $\begin{array}{c}\ln (\mathrm{A}) \\
(\mathrm{B})\end{array}$ & $\begin{array}{c}(\mathrm{B}) \\
(\mathrm{C})\end{array}$ & $\begin{array}{c}\text { (C) } \times 1.7987 \\
(\mathrm{D})\end{array}$ & $\begin{array}{c}\text { Accurate to } \\
\text { a decimal places (E) }\end{array}$ \\
\hline 1 & 0.0000 & 0.000 & 0.00 & 0.0 \\
2 & 0.6931 & 0.132 & 0.24 & 0.2 \\
3 & 1.0986 & 1.682 & 3.03 & 3.0 \\
4 & 1.3863 & 6.088 & 10.95 & 11.0 \\
5 & 1.6094 & 13.897 & 25.00 & 25.0 \\
6 & 1.7918 & 25.156 & 45.26 & $75.0^{\mathrm{a}}$ \\
\hline
\end{tabular}

ln: Natural logarithm; ${ }^{a}$ AIS code is 6 , LISS value of automatic promotion for 75 .

data sets enabled us to test the performance of NISS and LISS. NISS was computed according to Osler et al. ${ }^{[5]}$ LISS was computed as: AIS (2005 revision) codes taking the natural logarithm to a power of 5.53 multiplied by 1.7987 and then adding the three most severe (i.e. highest AIS) injuries, regardless of body region. LISS value is the sum of three round numbers in the E column (Table 1) after transforming AIS codes (Mathematical expression: LISS $=\left(\ln \mathrm{A}_{1}\right)^{5.53} \times$ $1.7987+\left(\ln \mathrm{A}_{2}\right)^{5.53} \times 1.7987+\left(\ln \mathrm{A}_{3}\right)^{5.53} \times 1.7987$. "In" indicates natural logarithm. $\mathrm{A}_{1}, \mathrm{~A}_{2}$, and $\mathrm{A}_{3}$ are the three most severe AIS codes). By way of example, a patient has 5 injuries as follows: Head AIS 5 and 2, Chest AIS 4, Abdomen AIS 2 and Lower Extremities AIS 3.
The three highest AIS codes are 5, 4 and 3. Therefore, LISS $=(\ln 5)^{5.53} \times 1.7987+(\ln 4)^{5.53} \times 1.7987+(\ln 3)^{5.53}$ $\times 1.7987=25+11+3=39$, while NISS $=5^{2}+4^{2}+3^{2}$ $=25+16+9=50$.

Comparisons between NISS and LISS were made using misclassification rates, receiver operating characteristic (ROC) curve analysis, and the Hosmer-Lemeshow (H-L) goodness of fit statistics by univariate and multivariate logistic regression model. Misclassification rates were defined as the sum of false-positives and false-negatives divided by the total number of cases. The area under the ROC curve was used to test sensitivity and specificity. The larger the area, the better the efficiency. The H-L statistic is a measure of

Table 2. Description of three study populations

\begin{tabular}{|c|c|c|c|}
\hline Data group & Hangzhou & Zhejiang & Shenyang \\
\hline All patients & 3784 & 4436 & 4018 \\
\hline Deaths $(\%)$ & $235(6.2)$ & $239(5.4)$ & $254(6.3)$ \\
\hline Sex (male, \%) & $2809(74.2)$ & $3030(68.3)$ & $2860(71.2)$ \\
\hline \multicolumn{4}{|l|}{ AIS of worst injury, $\mathrm{n}(\%)$} \\
\hline 3 & $2437(64.4)$ & $2890(65.1)$ & $2596(64.6)$ \\
\hline 4 & $937(24.8)$ & $1187(26.8)$ & $1016(25.3)$ \\
\hline $5-6$ & $410(10.9)$ & $359(8.1)$ & $406(10.1)$ \\
\hline Blunt injury & $3520(93.0)$ & $4137(93.3)$ & $3741(93.1)$ \\
\hline \multicolumn{4}{|l|}{ Mechanism, n (\%) } \\
\hline Motor vehicle collision & $1594(42.1)$ & $1564(35.3)$ & $1492(37.1)$ \\
\hline Accidental injury & $1015(26.8)$ & $1558(35.1)$ & $835(20.8)$ \\
\hline Fall & $548(14.5)$ & $832(18.8)$ & $1119(27.8)$ \\
\hline Violence & $320(8.5)$ & $131(2.9)$ & $300(7.5)$ \\
\hline Sharp instruments & $145(3.8)$ & $292(6.6)$ & $125(3.1)$ \\
\hline Other & $162(4.3)$ & $59(1.3)$ & $147(3.7)$ \\
\hline \multicolumn{4}{|c|}{ Body region of worst injury, $\mathrm{n}(\%)$} \\
\hline Head & $1872(49.5)$ & $1958(44.1)$ & $1928(48.0)$ \\
\hline Face & $303(8.0)$ & $194(4.4)$ & $263(6.5)$ \\
\hline Neck & $49(1.3)$ & $65(1.5)$ & $55(1.4)$ \\
\hline Thorax & $975(25.8)$ & $783(17.7)$ & $932(23.2)$ \\
\hline Abdomen and pelvic cavity & $506(13.4)$ & $364(8.2)$ & $415(10.3)$ \\
\hline Spine & $302(8.0)$ & $512(11.5)$ & $356(8.9)$ \\
\hline Upper limb & $398(10.5)$ & $471(10.6)$ & $450(11.2)$ \\
\hline Lower limbs and pelvis & $1400(37.0)$ & $1699(38.3)$ & $1429(35.6)$ \\
\hline External (Skin) and others & $708(18.7)$ & $311(7.0)$ & $636(15.8)$ \\
\hline
\end{tabular}


Table 3. Distribution of NISS and LISS categories in three data sets

\begin{tabular}{|c|c|c|c|c|c|c|c|}
\hline \multirow[t]{2}{*}{ NISS } & \multicolumn{7}{|c|}{ LISS } \\
\hline & $1-8$ & $9-15$ & $16-24$ & $25-40$ & $41-54$ & $55-75$ & Total \\
\hline \multicolumn{8}{|l|}{ Hangzhou } \\
\hline 9-15 & 1541 & 0 & 0 & 0 & 0 & 0 & 1541 \\
\hline $16-24$ & 792 & 251 & 0 & 0 & 0 & 0 & 1043 \\
\hline $25-40$ & 0 & 454 & 214 & 119 & 0 & 0 & 787 \\
\hline $41-54$ & 0 & 0 & 0 & 279 & 9 & 0 & 288 \\
\hline $55-75$ & 0 & 0 & 0 & 0 & 50 & 75 & 125 \\
\hline Total & 2333 & 705 & 214 & 398 & 59 & 75 & 3784 \\
\hline \multicolumn{8}{|l|}{ Zhejiang } \\
\hline $9-15$ & 1976 & 0 & 0 & 0 & 0 & 0 & 1976 \\
\hline $16-24$ & 745 & 631 & 0 & 0 & 0 & 0 & 1376 \\
\hline $25-40$ & 0 & 440 & 216 & 93 & 0 & 0 & 749 \\
\hline $41-54$ & 0 & 0 & 0 & 218 & 16 & 0 & 234 \\
\hline $55-75$ & 0 & 0 & 0 & 0 & 38 & 63 & 101 \\
\hline Total & 2721 & 1071 & 216 & 311 & 54 & 63 & 4436 \\
\hline \multicolumn{8}{|l|}{ Shenyang } \\
\hline $9-15$ & 1642 & 0 & 0 & 0 & 0 & 0 & 1642 \\
\hline $16-24$ & 835 & 363 & 0 & 0 & 0 & 0 & 1198 \\
\hline $25-40$ & 0 & 441 & 227 & 121 & 0 & 0 & 789 \\
\hline $41-54$ & 0 & 0 & 0 & 256 & 14 & 0 & 270 \\
\hline $55-75$ & 0 & 0 & 0 & 0 & 62 & 57 & 119 \\
\hline Total & 2477 & 804 & 227 & 377 & 76 & 57 & 4018 \\
\hline
\end{tabular}

the degree of calibration of a model. The result is evaluated by a Chi-square test. The smaller the values, the greater the correspondent rate. Data were statistically compared by Pearson's Chi-square test for categorical variables and Two-Related-Sample Wilcoxon onesample test or Two-Independent-Sample Mann-Whitney U test for continuous variance. Statistical analyses were performed using the Statistical Package for the Social Sciences (SPSS) 13.0 for Windows. A $p$ value of $<0.05$ was considered statistically significant. The study was approved by the institutional review board of Hangzhou Normal University.

\section{RESULTS}

A description of the study population is presented in Table 2. The patients' average age was $(44.9 \pm 18.6)$ years, $(50.6 \pm 19.6)$ years, and $(46.9 \pm 19.2)$ years in Hangzhou, Zhejiang, and Shenyang, respectively; approximately $93 \%$ of patients were bluntly injured. Approximately $94 \%$ survived to hospital discharge. The most frequently injured body regions were the head and extremities. The majority of patients were injured in motor vehicle collisions or due to accidental injuries or falls. The most frequent AIS code was 3 (approximately $64 \%$ ).

The majority of patients (approximately 98\%) had LISS values that were lower than NISS values. The LISS values of a few patients were equal to the corre- sponding NISS values. This result is expected, because all AISs values were 5 or 6 . In divergent observations, the difference between LISS and NISS values ranged from 1 to 18 , with a median of 10.6, 9.7, and 10.5 in Hangzhou, Zhejiang, and Shenyang, respectively. The median NISS and LISS values were 21.5, 19.3, and 20.9 and 10.9, 9.6, and 10.4, respectively.

Table 3 shows the proportion of patients whose injury severity category changed when the NISS was applied over the LISS. Where approximately $5 \%$ of patients had diverging values on a continuous scale, approximately $95 \%$ changed severity category when the LISS was applied. Overall, 2,335 (61.7\%), 3,079 $(69.4 \%)$, and 2,550 (63.5\%) patients moved one category and 1,246 (32.9\%), 1,185 (26.7\%), and 1,276 $(31.8 \%)$ patients moved two categories in Hangzhou, Zhejiang, and Shenyang, respectively.

When we examine the data set graphically, we see that the LISS better separates survivors from nonsurvivors. This impression is confirmed by the doubling of the separation of the median values for survivors and fatalities by LISS over NISS in both data sets (LISS median fatalities - LISS median survivors $=31.0,29.8$, and 29.7; NISS median fatalities - NISS median survivors $=28.3,27.9$, and 27.6 in Hangzhou, Zhejiang, and Shenyang, respectively) (Fig. 1).

The NISS and LISS were different in approximately $95 \%$ of the incidents. Fig. 2 show graphs of 
(a)

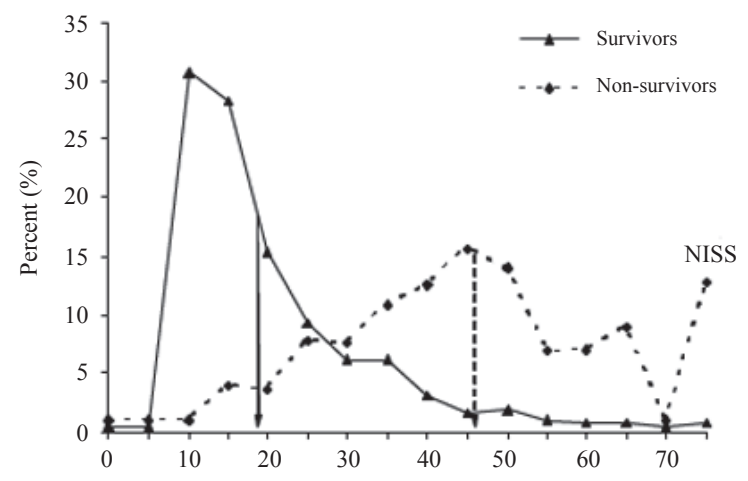

(b)

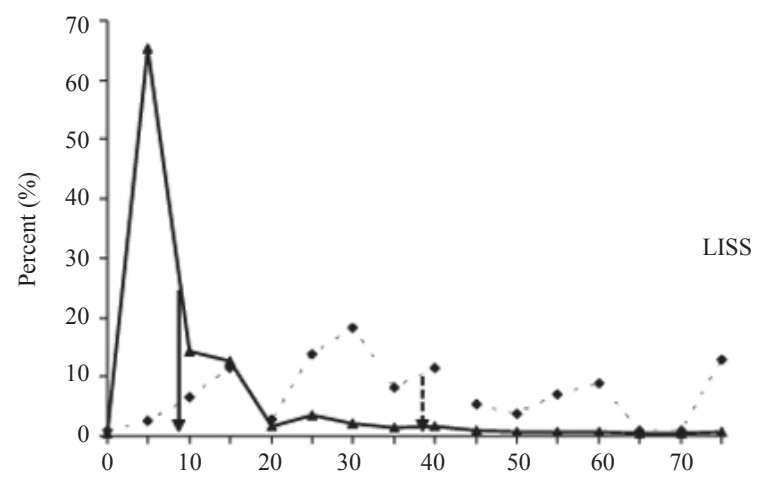

Fig. 1. Hangzhou, Zhejiang, and Shenyang data set frequency distributions for survivors and non-survivors as coded by NISS (a) and LISS (b). Arrows indicate median values, while they are twice as widely separated by LISS. Solid curve and arrow $=$ survivors, dashed line and arrow $=$ Non-survivors.

the NISS and LISS against actual mortality. It is seen that, although the lines are generally increasing, the NISS scores are very choppy and have nonmonotonic qualities. NISS graphs show a nonlinear trend, confirming earlier research. A great number of NISS mortality rates were distributed to the right of the auxiliary line. LISS mortality rates were uniformly distributed at two-sided auxiliary line.

A formal statistical analysis confirms the superior predictive power of LISS over NISS. A great number of measures examined were statistically significantly better for LISS than for NISS: ROC curve areas, H-L statistics, and mean values (Table 4). Only the misclassification rate was not statistically significantly improved under LISS.

\section{DISCUSSION}

The AIS severity score performs well as a measure of mortality, but that mortality is not the sole determinant of AIS severity. As AIS increased, variability in the survival also increased. This reflects the fact that when looking at mortality, there is such low mortality for all of the AIS 1 and 2 injuries that virtually no variability exists. Understandably, because factors other than mortality are involved in the AIS values, more complex injuries have wider variability. ${ }^{[3]}$ Therefore this study ignores those patients who have injuries with an AIS severity of 1 and/or 2. Data analyzed from 181,707 patients from the National Trauma Data Base $(\mathrm{NTDB})^{[3]}$ who sustained only a single injury. There was a superb, but non-linear correlation between AIS severity and survival (and mortality). The data fit a quadratic function nearly perfectly. The mortalities for the patients with one injury of AIS severity in ordinal scale of $3,4,5$, and 6 were $3.5 \%, 14.6 \%, 39.6 \%$, and $79.0 \%$, respectively. Their corresponding proportions were approximately 1: 4.2 (14.6\% divided by $3.5 \%)$ : 11.3: 22.6. How can we transform the relation from a quadratic function into a more intuitive linear function?

There are a variety of scoring methods. The ISS's ability to consider as many as three different injuries (a)

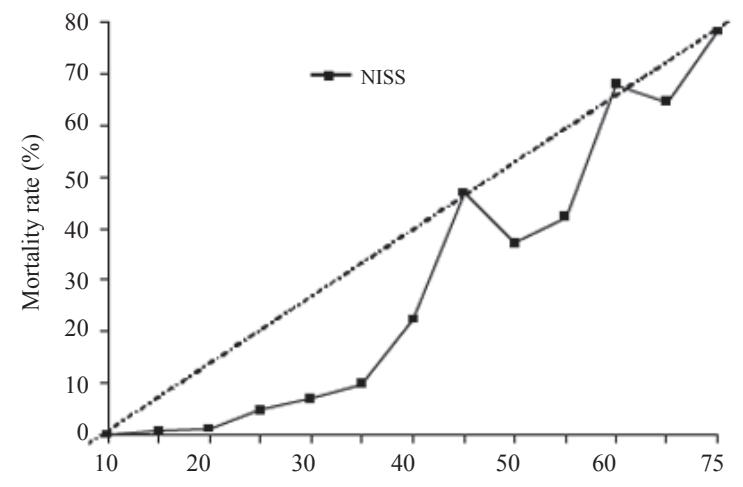

(b)

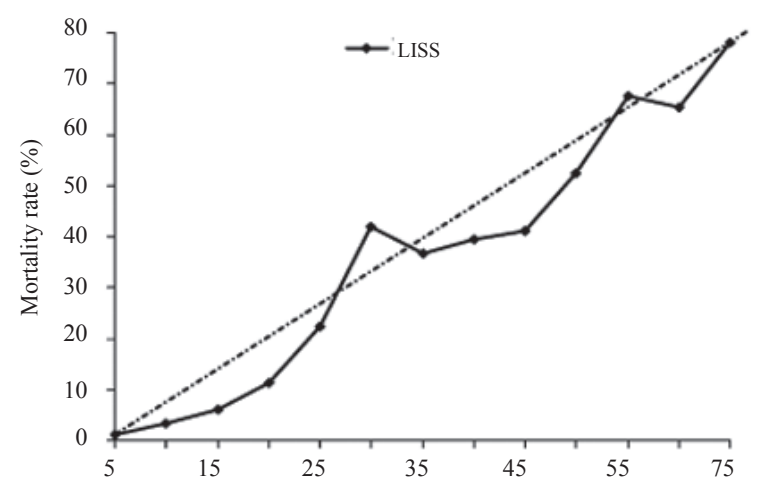

Fig. 2. Hangzhou, Zhejiang, and Shenyang mortality rates for different NISS (a) and LISS (b) values. Solid curve = NISS (a) and LISS (b). Dashed line is auxiliary line. 
Table 4. Comparison of NISS and LISS in predicting mortality in three data sets

\begin{tabular}{lccc}
\hline & NISS & LISS ${ }^{\mathrm{a}}$ & $p$ \\
\hline Hangzhou & & & \\
$\quad$ Misclassification (\%) & 4.18 & 3.91 & 0.551 \\
ROC & 0.931 & 0.949 & 0.006 \\
ROC 95\%CI & $0.918-0.944$ & $0.938-0.959$ & \\
Hosmer-Lemeshow & $15.76(\mathrm{p}=0.027)$ & $13.79(\mathrm{p}=0.055)$ & \\
Zhejiang & & & 0.637 \\
Misclassification (\%) & 4.26 & 4.06 & 0.019 \\
ROC & 0.911 & 0.935 & \\
ROC 95\%CI & $0.890-0.931$ & $0.921-0.953$ & 0.334 \\
Hosmer-Lemeshow & $22.70(\mathrm{p}=0.001)$ & $18.43(\mathrm{p}=0.005)$ & 0.014 \\
Shenyang & & & \\
Misclassification (\%) & 4.8 & 4.35 & \\
ROC & 0.918 & 0.936 & \\
ROC 95\%CI & $0.904-0.932$ & $0.921-0.953$ & \\
Hosmer-Lemeshow & $28.97(\mathrm{p}<0.001)$ & $17.45(\mathrm{p}=0.008)$ & \\
\hline a $<$ 0.001, Two-related-samples of the nonparametric Wilcoxon one-sample test, Comparison between LISS and NISS. \\
CI: Confidence interval; ROC: Receiver operating characteristic.
\end{tabular}

in its final outcome score represented a considerable advance over the earlier practice of summarizing a patient's injuries based on the single worst injury (maximum AIS), and today's modern trauma data bases routinely record all of the injuries sustained by a patient. It seemed likely to us that a more modern summary measure of trauma that could take advantage of this richer description of patients' injuries would more accurately predict outcome than the original ISS. NISS, by contrast, simply considers the three most severe injuries sustained by a patient and thus avoids this shortcoming of the traditional ISS. Many articles can be found in the literature that have compared the NISS favorably to the ISS in predictive mortality, so the research in this article will only compare LISS with NISS, and not ISS.

However, the ISS/NISS have an idiosyncrasy that impairs their predictive power. The ISS/NISS values for the patients with one injury of AIS severity in ordinal scale are $3,4,5$, and 6 in 9, 16, 25, and 75, respectively. Their corresponding proportions approximately are 1: 1.8 (16 divided by 9): 2.8: 8.6. Comparisons of the corresponding proportions between AIS and ISS/ NISS were made using 1 divided by 1 is equal to 1 , $4.2 / 1.8=2.3,11.3 / 2.8=4.0$, and 22.6/8.6 $=2.7$, respectively. Difference was at least one time more than if based on AIS 3. They showed that there are serious flaws in the ISS/NISS scoring.

There are many articles in the literature that describe the practical and statistical limitations of the ISS. Although the ISS is scaled from 1 to 75 , it actually takes just 44 distinct values, and these values are not uniformly distributed. Statistical comparisons of the 44 ISS values are scaled from 1 to $75, p=0.015$. Be- cause of this, some have suggested that the ISS should not be treated as a continuous measure but rather as an ordinal scale, which is mathematically correct, if thoroughly ignored.$^{[19]}$ Although LISS actually takes just 19 distinct values, these values are uniformly distributed $(p=0.130)$. The LISS values for the patients with one injury of AIS severity in ordinal scale are 3 , 4,5 , and 6 in $3,11,25$, and 75 , respectively. Their corresponding proportions are approximately $1: 3.7$ (11 divided by 3 ): $8.3: 25.0$. Their proportions roughly equal the mortality of each AIS code.

Some studies showed the differences for nonunique values of the ISS and NISS, respectively. The AIS triplets that produce identical ISS and NISS scores have markedly different mortality rates. ${ }^{[16-18]}$ Because our study patients were too few in number, we borrowed the data of Kilgo et al. ${ }^{[17]}$ to carry out the analysis. For instance, an ISS of 27 is possible in two groups of patients where $(5,1,1)$ had a $35.25 \%$ mortality rate in comparison with $11.31 \%$ in $(3,3,3)$, representing a $23.94 \%$ difference in mortality, even though their ISS scores are identical. The LISS adjusts its $(5,1,1)$ mortality rate to $35.25 \% \times(3+3+3) /$ $(25+0+0)=12.69 \%$, and comparing mortality rates AIS triplets $(5,1,1)$ and AIS triplets $(3,3,3)$ again, $\mathrm{p}=0.0693$. Similarly, several ISS values coming from different traumas lead to a change in the statistical significance of mortality. However, LISS lessens significant differences in mortality rates compared to the AIS triplets, which produce identical scores.

The LISS prediction of mortality is based solely on the anatomic information specified by a patient's AIS injury descriptors. We believe that part of the value of an injury summary score is that it can be calculated by clinicians. The popularity of the ISS/NISS has 
stemmed in some measure from its ease of computation. LISS inherits and extends this advantage, relying as it does on the AIS severities for each injury. This is a retrospective, non-concurrent cohort study that compares LISS with NISS values calculated at the time of discharge. A concurrent cohort study would presumably yield identical results, but would be of interest to further verify our results.

This study applies natural logarithm transformations of AIS severity that increase the gap between AIS values, although it appears to do this by collapsing the minor end of the AIS scale to zero, while the distribution provides better statistical characteristics. It shows a more accurate prediction of the prognosis, and displays a linear relation to mortality. The data fit a straight line nearly perfectly! Although the calculation of LISS is itself so complicated that a computer is required, the result is simple. This corresponds to the basic principles of the scoring system: that it is simple and easy to remember. Meanwhile, LISS is better in predicting outcome and it should replace the NISS and the ISS.

\section{REFERENCES}

1. Rating the severity of tissue damage. I. The abbreviated scale. JAMA 1971;215:277-80.

2. The Abbreviated Injury Scale 2005-Update 2008. Des Plaines, IL 60018: Association for the Advancement of Automotive Medicine; 2008.

3. Gennarelli TA, Wodzin E, editors. The Abbreviated Injury Scale 2005. Des Plaines, IL: Association for the Advancement of Automotive Medicine; 2005.

4. Baker SP, O’Neill B, Haddon W Jr, Long WB. The injury severity score: a method for describing patients with multiple injuries and evaluating emergency care. J Trauma 1974; 14:187-96.

5. Osler T, Baker SP, Long W. A modification of the injury severity score that both improves accuracy and simplifies scoring. J Trauma 1997;43:922-6.

6. Sullivan T, Haider A, DiRusso SM, Nealon P, Shaukat A, Slim M. Prediction of mortality in pediatric trauma patients: new injury severity score outperforms injury severity score in the severely injured. J Trauma 2003;55:1083-8.
7. Lavoie A, Moore L, LeSage N, Liberman M, Sampalis JS. The New Injury Severity Score: a more accurate predictor of in-hospital mortality than the Injury Severity Score. J Trauma 2004;56:1312-20.

8. Frankema SP, Steyerberg EW, Edwards MJ, van Vugt AB. Comparison of current injury scales for survival chance estimation: an evaluation comparing the predictive performance of the ISS, NISS, and AP scores in a Dutch local trauma registration. J Trauma 2005;58:596-604.

9. Hu Y, Tang Y, Yuan Y, Xie TP, Zhao YF. Trauma evaluation of patients with chest injury in the 2008 earthquake of Wenchuan, Sechuan, China. World J Surg 2010;34:728-32.

10. Tay SY, Sloan EP, Zun L, Zaret P. Comparison of the New Injury Severity Score and the Injury Severity Score. J Trauma 2004;56:162-4.

11. Bulut M, Koksal O, Korkmaz A, Turan M, Ozguc H. Childhood falls: characteristics, outcome, and comparison of the Injury Severity Score and New Injury Severity Score. Emerg Med J 2006;23:540-5.

12. Stephenson SC, Langley JD, Civil ID. Comparing measures of injury severity for use with large databases. J Trauma 2002;53:326-32.

13. Tamim H, Al Hazzouri AZ, Mahfoud Z, Atoui M, El-Chemaly $\mathrm{S}$. The injury severity score or the new injury severity score for predicting mortality, intensive care unit admission and length of hospital stay: experience from a university hospital in a developing country. Injury 2008;39:115-20.

14. Hannan EL, Waller CH, Farrell LS, Cayten CG. A comparison among the abilities of various injury severity measures to predict mortality with and without accompanying physiologic information. J Trauma 2005;58:244-51.

15. Moore L, Lavoie A, Le Sage N, Bergeron E, Emond M, Abdous B. Consensus or data-derived anatomic injury severity scoring? J Trauma 2008;64:420-6.

16. Russell R, Halcomb E, Caldwell E, Sugrue M. Differences in mortality predictions between Injury Severity Score triplets: a significant flaw. J Trauma 2004;56:1321-4.

17. Kilgo PD, Meredith JW, Hensberry R, Osler TM. A note on the disjointed nature of the injury severity score. J Trauma 2004;57:479-87.

18. Aharonson-Daniel L, Giveon A, Stein M; Israel Trauma Group (ITG), Peleg K. Different AIS triplets: Different mortality predictions in identical ISS and NISS. J Trauma 2006;61:711-7.

19. Krischer JP. Indexes of severity: underlying concepts. Health Serv Res 1976;11:143-57. 